\title{
クラックテンソルによる節理性岩盤の弾性変形解析と 入力パラメーターの決定に関する研究*

\author{
PARAMETER DETERMINATION IN ELASTIC ANALYSIS OF \\ JOINTED ROCK MASSES BY CRACK TENSOR THEORY
}

\author{
山辺 正**.原夏生*** - 小田匡寛 ${ }^{* * * *}$
}

By Tadashi YAMABE, Natsuo HARA and Masanobu ODA

\begin{abstract}
Stress strain relations of rock masses are considerably different from that of intact rocks due to the presence of geological discontinuities such as joints and faults. In this paper, finite element analyses on these discontinuous materials are performed by using the elastic compliance tensor in terms of "Crack Tensor" proposed by Oda (1983) with the conclusion that the crack tensor approach provides a sound basis for approximating linear and non-linear elastic behaviour of rock masses. It has also become clear that input parameters for the finite element analyses can be determined by analyzing conventional tests on geological materials both in laboratory and in-situ.

Keywords : crack tensor, elastic analysis, parameter determination
\end{abstract}

\section{1.はじめに}

岩盤には本来，多数の不連続面が存在し，その規模の 大小や成因により断層, 層理, 節理などとよばれている. 岩盤の力学挙動を的確に把握するためには, これらの不 連続面の力学的評価が重要であることはいうまでもな い. たとえば, 従来, 不連続面そのものや多数の不連続 面を含むモデル供試体を用いて, その力学特性を実験的 に研究した例 ${ }^{1) （ 5)}$ は不連続性岩盤を理解しようとする努 力の現われである. しかし, それらのモデル実験による 研究成果を実岩盤の評価に活かすには何らかの指導原理 によって, モデルと実岩盤の力学的な等価性を証明しな ければならない.一方, 不連続性岩盤を数值解析的に扱っ た従来の研究では, 不連続面の位置や規模さらに力学性 に関する情報があらかじめ確定できる問題に対して, ジョイント要素を導入するなどの手法 ${ }^{6), 7)}$ を採用してき た. 大規模な断層なよ゙にジョイント要素を適用して解析

* 本論文の一部は, 第 17 回, 第 18 回岩盤力学に関するシ ンポジウム ${ }^{24), 25)}$ および第 1 回地盤工学における数値解 析法シンポジウム ${ }^{26)}$ において発表している.

** 正会員 工修 埼玉大学助手 工学部建設基礎工学科 ( (338 浦和市下大久保 255)

*** 学生会員 埼玉大学大学院工学研究科 (同上)

**** 正会員 工博 埼玉大学助教授 工学部建設基礎工学科 (同上)
するなどの例はその好例である，しかし，いかに計算機 の利用が普及したとはいえ，規模の小さい多くの節理の すべてをジョイント要素で置き換え，それらの物性を踏 まえた数值解析を実行することは不可能ではないにして も，非現実的であると思われる．多くの不連続面を有す る岩盤と水理・力学的に等価な連続体を定義する一般的 手法の開発が待たれるゆえんである. 近年, 特に種々の エネルギー施設を初め, 多くの重要構造物が岩盤内に建 設されようとしている. その際，生ずると思われる諸問 題を解決するためには，岩盤における応力ーひずみ関係 のみならず, 熱, 浸透などの現象との連成をも考虑し得 る解析手法を確立しなければならない。すでにさまざま な実規模の原位置試験を行い，その検討を開始している 例 $^{8)}$ をると亀裂を含む岩盤の力学挙動が非線形になる ことが連成現象を考えるうえで大きな問題となることが わかる.ただし, 連成問題を解明するためには, まず個々 の現象に対するクラックの影響を解明しておく必要があ る.このような現状認識を踏まえ, 小田は, 亀裂の幾何 学的特性を一般的に表現するクラックテンソルの概念を 提唱( ${ }^{9)-11)} こ の$ 概念が材料の力学的な特性を記述するう えでも有効な指標となり得ることを明らかにしている. このクラックテンソルによれば，亀裂を含む材料を等価 な異方弾性体として評価し, その弾性コンプライアン 
ス $^{12)}$ や降伏条件 ${ }^{13)}$ を与えるだけでなく，等価な異方透水 性 ${ }^{14)}$ の弾性多孔質媒体の支配方程式 ${ }^{15)} も$ 表現し得る量 であることが大きな特徴といえる．本研究では，クラッ クテンソルの概念を適用し変形問題に限定した場合の有 限要素解析プログラム (Non-linear Elastic Analysis by Crack tensor theory, NEAC) を作成し，それを用 いて亀裂を含む岩盤と等価な力学モデルに対する線形お よび非線形弾性解析を行う。また, 数值解析に必要な入 カパラメーターの決定方法について詳細に検討する.さ らに，それらのパラメーターが原位置や岩盤モデルとし ての多亀裂性の岩石に対して容易に決定できることを示 す、なお，本研究では，多くの亀裂を含み，それらが統 計的に均質とみなせる岩盤を対象としている。したがつ て，たとえば，断層のような領域を横断する規模の大き い亀裂は別に考察する必要がある.

\section{2. クラックテンソルによる弾性コンプライア ンスの定式化}

多数の亀裂を含む岩盤の变形解析を行ううえで必要な クラックテンソルに関する関係式占)を列記しておく。ま ずクラックテンソルは, 式 (1) で表わされる偶数階の テンソルである.

$$
\underbrace{F_{i j \cdots k}^{(l)}}_{p}=\frac{\pi \rho}{4} \int_{0}^{r_{m}} \int_{\Omega} r^{l} \underbrace{n_{i} n_{j} \cdots n_{k}}_{p} E(\boldsymbol{n}, r) d r d \Omega \cdots(1)
$$

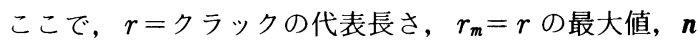
ニクラックの単位法線ベクトル, $\rho=$ 単位体積当たりの クラック数, $E(\boldsymbol{n}, r)=\boldsymbol{n}$ と $r$ の分布を表わす確率密 度関数, $\Omega=$ 全立体角, $p=$ 階数, $l=$ 次数を表わす.

このクラックテンソルは明確な幾何学的意味をもつ ${ }^{91}$ が、ここでは論じないことにする。 ただし，式（1）の 積分形は, 例として 2 階を取り上げると次式の加算形で も書き表わせることを付け加えておく.

$$
F_{i j}^{(3)}=\frac{\pi}{4 V} \sum_{k=1}^{m(n)}\left(r^{(k)}\right)^{3} n_{i}^{(k)} n_{j}^{(k)}
$$

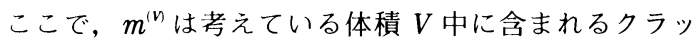
クの総数であり $m^{(n}=\rho V$ である. その他は, 式 $(1)$ の定義に用いられている量と同じ意味をもつ.ただし， （ $k$ ）は単に $k$ 番目であることを表わし，総和規約に従 わない。 なお, 本研究で取り扱うような弾性問題に限れ ば，用いるクラックテンソルの次数はすべて 3 と置ける ので, $F_{i j}^{(3)}=F_{i j}$ であるが, 亀裂性岩盤の透水テンソル を考える場合には $l=5$ とするテンソルが重要となる ${ }^{15)}$. なお，クラックを含む領域をテンソル量によって表現し ようとする従来の試みは主に金属を対象とする研究分野 で行われてきた。岩盤を対象とした例としては，“損傷 力学” の概念を適用した京谷ら ${ }^{16)}$ の研究がある.また,
金谷はステレオロジーの立場からテンソル量を定義し， 岩盤において二次元の亀裂情報から三次元構造を推定す る試みを発表している ${ }^{17)}$.

岩盤に含まれるクラックを 2 枚の平板で置き換え，そ の力学的性質を 2 枚の板を連結する垂直ばね，せん断ば ねで表わせるものとする ${ }^{15)}$. 従来の実験事実 ${ }^{4), 5), 18)}$ に若 干の考察を加えて,ばねの垂直剛性 $K$, せん断剛性 $G$ は, それらの応力依存性を考慮して次式で近似できる.

$$
\begin{aligned}
& \bar{K}=\left(K_{0}+C \bar{\sigma}_{i j} N_{i j}\right) / r=K(\overline{\boldsymbol{\sigma}}, \boldsymbol{N}) / r \\
& \bar{G}=\left(G_{0}+G_{1} \bar{\sigma}_{i j} N_{i j}\right) / r=G(\overline{\boldsymbol{\sigma}}, \boldsymbol{N}) / r
\end{aligned}
$$

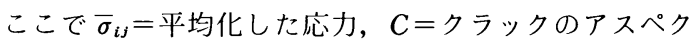
卜比（クラックの初期厚さを $t_{0}$ とすれば式（1）の $r$ を用いて， $C=r / t_{0}$ で表わされる. ) $, K_{0}, G_{0}, G_{1}=$ ばね に関する物理定数である. また, $N_{i j}$ は,

$$
N_{i j}=\int_{\Omega} n_{i} n_{j} E(\boldsymbol{n}) d \Omega
$$

之書かれ, $E(\boldsymbol{n})$ はクラック方向の確率密度関数である. 式（1）の積分形を式（2）の加算形に直したように式 （5）は加算形で書くこともできる.ここで，式（3), （4）に関連して特に次の二点に注意したい。））過去 の多くの実験によると, $\bar{K}, \bar{G}$ はクラック面への垂直応 力 $\sigma_{i j} n_{i} n_{j}$ に強く依存することが知られている. 式 (3), （4）では，個々の垂直応力を考える代わりに領域 $V$ に あるクラックの平均的垂直応力 $\bar{\sigma}_{i j} N_{i j}$ に置き換える平 均化が施されている．ii）岩盤の力学定数の寸法効果は 力学解析を実岩盤へ適用するうえで考慮すべき重要なポ イントである. 式（3)，（4）ではその寸法効果が $1 / r$ の形式で表現されていて, Bandis ら ${ }^{5)}$, Yoshinaka $ら^{18)}$ の実験結果とも整合的である.

亀裂を含む岩盤全体の変形が岩盤を構成する岩石実質 部分の変形亡亀裂部分の変形の和で表わされるとし，そ れぞれの弾性コンプライアンスを $\bar{T}_{i j k l}, \bar{M}_{i j k l}, \bar{C}_{i j k l}$ とす れば，これらの間には次の関係が成立する.

$$
\bar{\varepsilon}_{i j}=\bar{T}_{i j k l} \bar{\sigma}_{k l}=\left(\bar{M}_{i j k l}+\bar{C}_{i j k l}\right) \bar{\sigma}_{k l}
$$

ここで， $\bar{\varepsilon}_{i j}$ は平均化したひずみであり，岩石実質部分 に対して等方均質な弾性体を仮定すれば， $\bar{M}_{i j k l}$ は，ヤ ング率 $E$, ポアソン比 $\nu$ を用いて次式で表わせる.

$$
\bar{M}_{i j k l}=\frac{1+\nu}{E} \delta_{i k} \delta_{j l}-\frac{\nu}{E} \delta_{i j} \delta_{k l}
$$

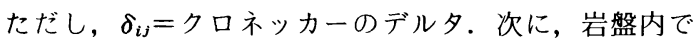
考えた測線に沿って，クラックに垂直な相対変位および せん断方向の相対変位を考慮して, 測線方向の変位の総 和を求め, それと等価なひずみテンソルを求めることに より $\bar{C}_{i j k l}$ は， 2 階，4階のクラックテンソルおよび式 ( 3 )，（4）の $K(\overline{\boldsymbol{\sigma}}, \boldsymbol{N}), G(\overline{\boldsymbol{\sigma}}, \boldsymbol{N})$ を用いて次式とな $ろ^{15)}$. 


$$
\begin{aligned}
\bar{C}_{i j k l}= & \left\{\frac{1}{K(\bar{\sigma}, N)}-\frac{1}{G(\bar{\sigma}, N)}\right\} F_{i j k l} \\
& +\frac{1}{4 G(\bar{\sigma}, N)}\left(\delta_{i k} F_{j l}+\delta_{j k} F_{i l}+\delta_{j l} F_{i k}+\delta_{i l} F_{j k}\right)
\end{aligned}
$$

ただし, 式（8）の導出にあたっては, 式（9）で表わ されるコンプライアンスの対称性を用いている.すなわ ち式（8）で与えられるコンプライアンスは, Greenの 弾性体の意味で次の対称性を満足している.

$$
\bar{C}_{i j k l}=\bar{C}_{j i k l}=\bar{C}_{i j l k}=\bar{C}_{k l i j}
$$

式（8）に含まれる $K, G$ は応力に依存しているので, 式（6)（８）は, 異方性を有する非線形弾性体の弾性 コンプライアンスを与える. 式 (8) において, 特に, $K=G=3 \pi E / 8$ と置いたときは, クラックの形状を penny-shape に仮定した弾性解と一致する.ここで, $E$ は岩石実質部分のヤング率である.そのとき式（８）は, 次式となる.

$$
\bar{C}_{i j k l}=\frac{2}{3 \pi E}\left(\delta_{i k} F_{j l}+\delta_{j k} F_{i l}+\delta_{j l} F_{i k}+\delta_{i l} F_{j k}\right)
$$

式（10）は式（8）と同様, クラック相互間の弾性干渉 を無視した線形異方弾性体の弾性コンプライアンスを与 えている.これらの弾性コンプライアンスの適用にあ たっては, 対象とする構造物の重要度や, 構造物の種類, 岩盤の状況などに応じて必要とされる調査の精度が異な ると同様に, $\bar{C}_{i j k l}$ を式 (8) の非線形弾性体とするか, 式 (10) の線形弾性体とするかを選択して用いるべきで ある. 式 (10) を用いる場合, 現実の岩盤に存在するク ラックの一部が閉じていて, 岩石実質部分がクラック内 で bridge 状に連結していることに注意したい。この効 果を近似的に表わすために, 式（1）において $r$ が, 観察されるトレース長より短くなっていることを考慮し

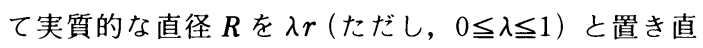
すことができる.このとき $r$ に代わって $R$ を用いた場 合の二階のテンソルを $f_{i j}{ }^{(3)}$ と書けば, さきに定義した $F_{i j}{ }^{(3)}$ と次式で関係ゔけられる.

$$
f_{i j}^{(3)}=\lambda^{3} F_{i j}^{(3)}, 0 \leqq \lambda \leqq 1
$$

岩盤を線形異方弾性体として解析する場合には, 式 (10) 中の $F_{i j}{ }^{\left({ }^{3}\right)}$ を式 (11) で与えられる $f_{i j}{ }^{(3)}$ で置き 換えた弾性コンプライアンスを適用することが，より現 実的であると思われる.

\section{3. 多数の不連続面を含む岩石供試体の圧縮試 験}

多数の不連続面を含む岩石供試体を用いて，前節に示 したクラックテンソルによる構成式の検証を行うデータ を得るため, その力学挙動を実験的に調べた ${ }^{19)}$.

実験では, 岩石供試体として長野県下伊那郡の大西山 崩壊現場で採取したブロック状のミロナイト(mylonite) を用いた. 大西山の崩壊は 1961 年 6 月の豪雨によって 引き起こされ, 300 万 $\mathrm{m}^{3}$ 以上の土砂が堆積したとの報 告があり, その岩肌は非常にクラックが発達している. 岩石の顥微鏡観察によると, 基質部は新鮮で比較的均質 であり,クラックは充填物としてクロライト (chlorite) が認められた。採取したミロナイトをダイヤモンド・ カッターにより直方体に整形した後, 供試体の展開図を 作成した. 展開図の一例を Fig. 1 に示すが, 展開図上の クラックのスケッチに際して肉眼で観察しにくいクラッ クについては, 染色探傷剤（スーパーチェック）を用い てその存在を明確にした後, より客観的にクラックを観 察した。 なお, Fig.1中, 縦方向の太線と番号は, 供試 体表面に貼り付けたひずみゲージの一部を示している. 供試体には, 1 本当たり平均 20 枚のひずみゲージと, 場合によっては, 数本の $\pi$ ゲージを貼付けおのおのの 計測を行った.ゲージ長の長い塑性ゲージで供試体全体 にわたる軸方向および横方向のひずみを計測し，3方向 ロゼット・ゲージで基質部のひずみを測定した。さらに 供試体全体にとって, 支配的な挙動をすると思われる特 定のクラックについては, そのクラック上にゲージ長の 短い塑性ゲージを軸方向と横方向に貼り, あるいは $\pi$ ゲージを用いてそのクラックに沿った垂直方向およびせ

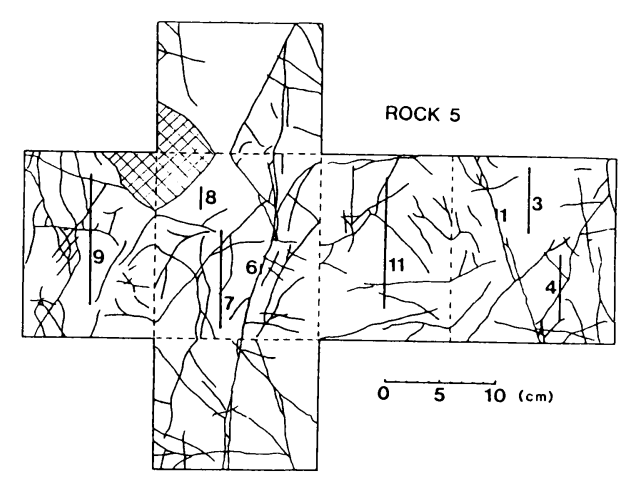

Fig. 1 Traces of cracks on surfaces of mylonite sample (Straight lines with numbers show strain gages).

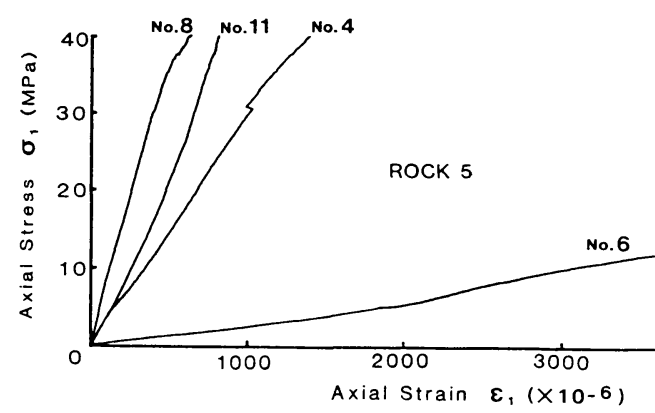

Fig. 2 Stress strain relation of cracked sample with the gage number of Fig. 1. 
ん断方向の変位を測定した。このように準備した供試体 の一軸圧縮試験を行い各ゲージによって計測された供試 体軸方向のひずみと, 軸方向に与えた応力との関係の一 例を Fig. 2 に示す. Fig. 2 のゲージ番号は, Fig. 1 の縦 方向ゲージの番号に対応するものであり, 局所的な変形 の様子がよく捉えられている. すなわち，卓越する不連 続面に沿って非常に大きな軸ひずみが測定されており

(No.6), 基質部分での軸ひずみは直線的で (No.8), 全体にわたる長いゲージはその中間程度のひずみ

(No.11) を示している.これらの縦ひずみに関する計 測結果は, そのゲージを貼付けた位置の局所的な挙動を 示すにすぎないので, 供試体の平均縦ひずみを次の要領 で求める。１）供試体全体にわたる塑性ゲージの貼られ ている側面では, そのデー夕を, その側面の縦ひずみと する. ii ） ゲージ長の長いひずみゲージが貼られていな い側面では，数枚の縦方向のゲージで計測されたひずみ をそのゲージ長に対応する変位量に直し，それらの総和 を, 各ゲージ長の総和で除し, その側面における縦ひず みとする， iii）ｉ），ii）の手順で求めた各側面の縦ひ ずみを単純平均して, 供試体全体の平均縦ひずみを定義 する.この平均縦ひずみと軸方向応力との関係を Fig. 3 に示す。なお，同図には基質部のゲージから求めたヤン グ率に相当する直線を without joint として入れてある. この結果から, 供試体の平均縦ひずみ一応力関係は, 初 期に下に凸の非線形な挙動を示した後に，直線的な部分 が現われ，最終的に塑性ひずみが卓越する傾向になるこ とがわかる.この実験結果と解析結果との比較は 6. に おいて行う.

\section{4. 入カパラメーターの決定方法に関する検討}

クラックテンソルを用いた定式化に必要なパラメー ターは，すでに示したとおりであり次の 3 種類に分ける ことができる。すすなわ，クラックの幾何学性から決定 される $\left(\boldsymbol{F}^{(3)}, \boldsymbol{N}\right)$, クラックの力学性から決定される $\left(K_{0}, C, G_{0}, G_{1}\right)$ および基質部の変形性を示す $(E, \nu)$ である、本節では，これらパラメーターの決定方法につ

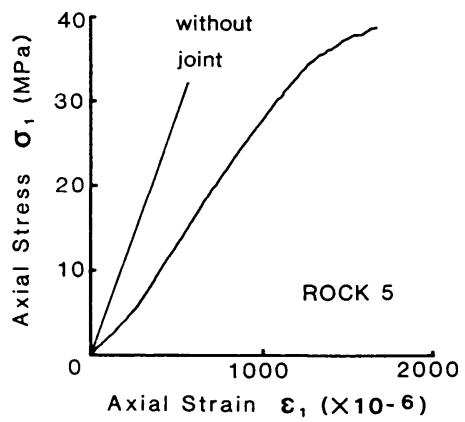

Fig. 3 Axial stress vs, mean axial strain.
いて順次，考察を進めることとする.

\section{（1） クラックテンソルの決定}

クラックテンソル $\boldsymbol{F}^{(3)}$ を決定するとき，式（1）を用 いる場合には $E(\boldsymbol{n}, r)$ を決定する必要がある。ただし， 式（1）と等価な式（2）の加算形を適用する場合には, 露頭で観察されるクラックのトレース長さの分布などを 用いることができる。ここで，Fig. 1 の展開図を利用し て各クラックの法線方向と代表長さを決定し, 式 (2) に従いクラックテンソル $F_{i j}$ を決定すると， $F_{i j}$ の各成 分は Table 1 の ROCK 5 となる. 同様の手法により, その他のサンプルについて $F_{i j}$ を求めた結果を Table 1 にまとめて示す．基底には右手系を採用し， $\boldsymbol{e}_{1}, \boldsymbol{e}_{2}, \boldsymbol{e}_{3}$ 方向は，それぞれ供試体の高さ，幅，奥行き方向に対応 する．また， Table 1 に与えた $F_{0}$ は， $F_{i j}$ の跡 (trace) で 0 階のクラックテンソルであり,その值が大きいほど, クラック密度が高いことを示す。さらに， $\xi^{(F)}$ は，三次 元の場合, 次式で与えられ，異方性の程度を表わす。

$$
\xi^{(f)}=\sqrt{3}\left(F_{i j} F_{j i}-\frac{1}{3} F_{0}^{2}\right)^{1 / 2} / F_{0}
$$

したがって式 (12) において $\xi^{(n)}=0$ であればクラック の向きと大きさが全くランダムな完全な等方性, $\xi^{(\mathfrak{F}}=$ $\sqrt{2}$ であればクラックがすべて同一の方向に配列してい る完全な異方性を表わす。

このように, クラックの展開図さえあれば $F_{i j}$ を決定 することができるが，常に三次元的なクラックパターン を必要とするわけではなく二次元の情報から三次元の亀 裂情報を推定する研究が小田 ${ }^{11)}$, 金谷 ${ }^{17)}$ らよって行わ れている。

\section{(2) $K_{0} / C \gamma^{\prime}$ について}

Fig. 4 は, Snow ら ${ }^{20)}$ が花崗岩種を対象に測定した亀 裂の開口幅 $t(\mu \mathrm{m})$ の深さ $Z(\mathrm{~m})$ 方向への変化を表 わす．図中の破線は応力に依存する垂直剛性を用いて深 さ方向に変化する開口幅 $t$ を推定した次式 ${ }^{15)}$ である.

$$
t=t_{0}\left(1-\frac{Z}{K_{0} / C \gamma^{\prime}+Z}\right)
$$

\begin{tabular}{|c|c|c|c|c|}
\hline & $\left(\begin{array}{l}F_{11} \\
\text { Sym. }\end{array}\right.$ & $\begin{array}{l}F_{12} \\
F_{22}\end{array}$ & $\begin{array}{l}F_{13} \\
F_{23} \\
F_{33}\end{array}$ & $\begin{array}{l}F \\
\xi^{(F)}\end{array}$ \\
\hline ROCK 2 & {$\left[\begin{array}{l}3.64 \\
\text { Sym. }\end{array}\right.$} & $\begin{array}{l}0.34 \\
2.29\end{array}$ & $\begin{array}{l}1.10 \\
0.48 \\
6.96\end{array}$ & $\begin{array}{r}12.89 \\
0.51\end{array}$ \\
\hline ROCK 3 & {$\left[\begin{array}{l}1.10 \\
\text { Sym }\end{array}\right.$} & $\begin{array}{l}0.41 \\
2.37\end{array}$ & $\begin{array}{r}-0.18 \\
-0.10 \\
0.52\end{array}$ & $\begin{array}{l}3.99 \\
0.65\end{array}$ \\
\hline ROCK 4 & {$\left[\begin{array}{l}7.29 \\
\text { Sym. }\end{array}\right.$} & $\begin{array}{l}1.71 \\
4.18\end{array}$ & $\begin{array}{r}-1.00 \\
-0.74 \\
4.93\end{array}$ & $\begin{array}{r}16.40 \\
0.40\end{array}$ \\
\hline ROCK 5 & {$\left[\begin{array}{l}2.50 \\
\text { Sуm. }\end{array}\right.$} & $\begin{array}{r}-0.11 \\
3.35\end{array}$ & $\begin{array}{r}-0.33 \\
0.03 \\
2.04\end{array}$ & $\begin{array}{l}7.89 \\
0.23\end{array}$ \\
\hline
\end{tabular}

Table 1 Crack tensor components of mylonite samples. 
ここで, $t_{0}$ は地表におけるクラックの開口幅 $(\mu \mathrm{m})$, $K_{0}$ と $C$ は垂直剛性を定義した式（3）に現われるパラ メータ一, また $\gamma^{\prime}$ は水中単位体積重量である. Snow のデー夕と適合させるためには $t_{0}=200(\mu \mathrm{m}), K_{0} /\left(C \gamma^{\prime}\right)$ $=20(\mathrm{~m})$ が選ばれている.この $t_{0}$ および $K_{0} / C \gamma^{\prime}$ を用 いた式（13）は, Snow の報告した透水係数の鉛直方向 変化の実測値をもよく説明していて ${ }^{15)}, K_{0} /\left(C \gamma^{\prime}\right)=20$ (m) は, 花崗岩質の岩盤に関する限り, 信憑性の高い 数値と考えられる. またCarlsson らが花崗岩質岩盤か

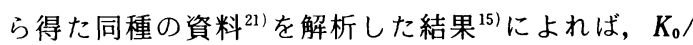
$\left(C \gamma^{\prime}\right)=10(\mathrm{~m})$ となる．このように花崗岩質岩盤では $K_{0} /\left(C \gamma^{\prime}\right)=10$ 20 (m) になるとともに次のような物理 的説明が可能である. すなわち, クラックの偏平性が大 きく(アスペクト比 $C$ が大きく), 鉛直方向ばねが弱い

（ $K_{0}$ が小さい）ときには, $Z$ の增分に対する $t$ の減少 率が大きいことを意味し，透水性に決定的な影響を与え る. 深さ方向の開口幅 $t$ や透水係数 $k$ の変化が実测で きる場合には，その変化に最も適合する $K_{0} /\left(C \gamma^{\prime}\right)$ を求 める. しかし，対象とするすべての岩盤に対してこのよ うなデータを採取することは一般には難しい.そのよう な場合， $K_{0} /\left(C \gamma^{\prime}\right)=10 \sim 20(\mathrm{~m})$ を目安として採用する ことができる.ただし，これらの値は国外の岩盤に対し て得られたデータであることに留意する必要がある.

次に，不連続面に対して垂直剛性を求める試験方法を 利用して $K_{0}, C$ を決定する方法を論ずる. 従来, Goodman らの方法に従ってジョイント要素に用いる物 性值としての垂直剛性 $K_{n}$ を求めるために, ジョイント を挟む供試体を用いて重直応力 $\sigma_{n}$ と垂直変位 $\delta_{n}$ の関係

(Fig.5) が, 利用される.この図において, ある応力 レベルに対する割線の傾きは式 $(3)$ の記号を用いると, その応力状態 $\bar{\sigma}_{i j}$ に対する垂直剛性 $\bar{K}$ であり, 式 $(2)$ の $N_{i j}, r$ は, クラックの幾何学的性質から判明してい るので, $\left(\bar{\sigma}_{i j}, \bar{K}\right)$ を 2 組求めて連立させることにより

$\left(K_{0}, C\right)$ を決定できる.ただし, 代表として取り上げ たジョイントに対する計測結果が，他のジョイントにも 適用できるものであるかどうかの検討が必要であり，多 数のジョイントに対するデータがあれば，それらを併用 してパラメーターを決定することが望ましい. また, 地 表付近のように応力レベルが低く風化作用を受けやすい ジョイントでは, その開口幅も広く，粘土を挟在するこ とが一般的で, パラメーターの決定には注意を要する.

Fig. 4 のデータに関しても地表 $(Z=0 \mathrm{~m})$ における観 測値として $t=900(\mu \mathrm{m})$ との報告もある.

( 3 ) $G_{0}, G_{1}$ について

式（4）に含まれるパラメーターについて考える. 非 常に広範な垂直応力と多数の供試体を用いたせん断剛性

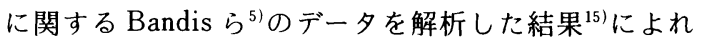

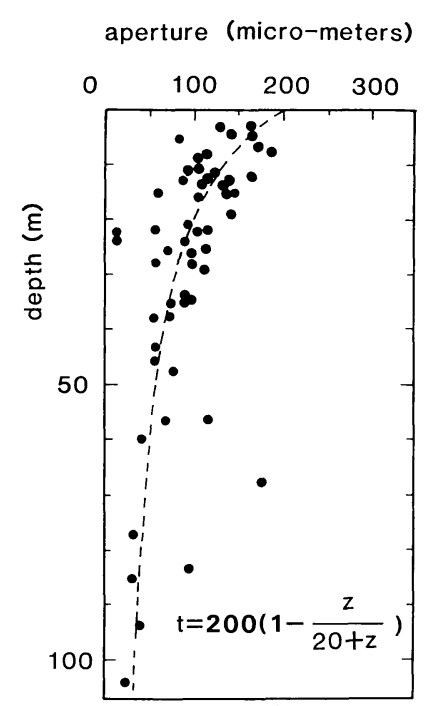

Fig. 4 Change of fracture aperture by depth below surface (Bianchi and Snow, 1968) and estimated curve using eq. (13).

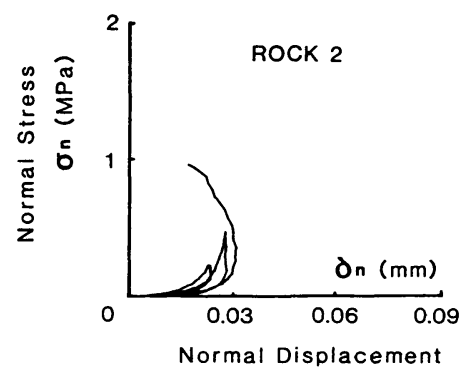

Fig. 5 Normal stress vs. normal displacement.

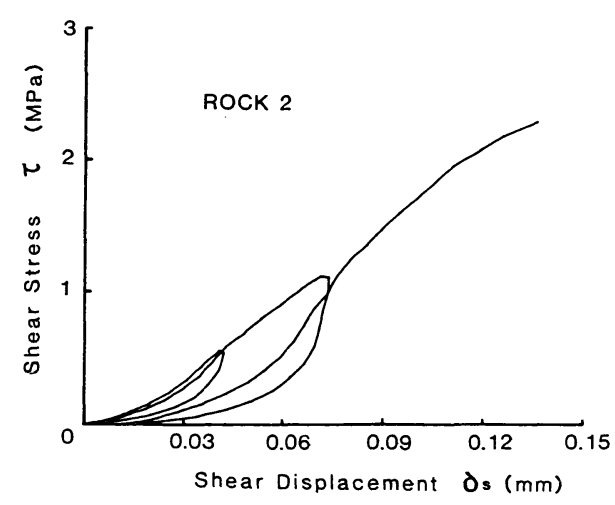

Fig. 6 Shear stress vs. shear displacement.

ば, せん断剛性 $\bar{G}$ とクラックの代表長さ $r$ とは垂直応 力をパラメーターとして逆比例の関係にある. その傾き は両対数紙上でー 1 であり $G_{0}=0$ としたとき無次元数 $G_{1}$ は $G_{1}=200$ と近似される， $G_{1}$ に関する他の情報が得 られないときには,このデータを直接用いることも可能 である，ただし，これは自由に分離できる状態にある不 
連続面に対して得られた值でありしかも，低応力下での 近似の程度が劣るので，一般には，式（4）に示したよ うに， $G_{0}$ を付け加えることが望ましい。したがって， $\left(G_{0}, G_{1}\right)$ についても $\left(K_{0}, C\right)$ を決定したと同様に従来 行われてきたGoodman の手法について検討してみる.

Fig. 6 は，多数の亀裂を含む岩石のある特定の不連続面 上で計測した，その面に対するせん断応力〜せん断変位 関係の一例である．同図において，ある応力レベルに対 する割線の傾きは，その応力状態 $\bar{\sigma}_{i j}$ に対するせん断剛 性 $\bar{G}$ を与える。また，クラックの幾何学性から $r, N_{i j}$ は求められるので, 式 $(4)$ 中の $\left(\bar{G}, \bar{\sigma}_{i j}, r, N_{i j}\right)$ は既 知となり， $G_{0}, G_{1}$ を決定できる。なお，クラックテンソ 儿を用いて等価な線形異方弾性体を定義する式 (10),

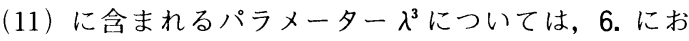
いて解析結果とまとめて議論する.

\section{（4）岩石実質部分の弾性コンプライアンス}

岩石実質部分の弾性定数について考える. 式（7）に 示したとおり，実質部分に等方均質な弾性体を仮定する 限り, 必要なパラメーターはヤング率 $E$, ポアンン比 $\nu$ の 2 種類のみである．実質部分の微視的な異方性の影響 が，クラックの存在による岩盤全体の異方性と比較して 無視し得ない程度であれば, 式 $(7)$ の $\bar{M}_{i j k l}$ を異方弾 性体の弾性コンプライアンスに変更すべきである。ただ し $, K_{0}, C, G_{0}, G_{1}$ などクラックの力学性に関するパラ メ一夕一の決定精度と比較してもなお， $\bar{M}_{i j k l}$ を異方性 にしなければならない場合は稀であると考えられる。し たがって，本論文ではすべての場合に， $\bar{M}_{i j k l}$ を等方均 質な弾性体の弾性コンプライアンスとした。

\section{5. 解析手法の特徴}

本研究で用いた有限要素解析コード (NEAC) は, 三次元の等方線形弾性体の解析に使われる一般的なプロ グラムの応力ーひずみ関係を式（8）で与えられるコン プライアンスの逆マトリックスに変更するだけで, 基本 的には容易に作成することができる，ただし，式（8) には，応力状態に応じて值の変化する項 $(K, G)$ が含 まれるので，反復計算を行う必要がある．たとえば，変 形を与える問題では，要素内の応力を判定規準にとり，

Fig. 7 の要領で収束させていく，すなわち，第 1 ステッ プではある与えた変形に対応する弾性解 $\left(A_{1}\right)$ を求め, その応力 $\sigma^{(1)}$ 加，式 (3)，(4) の $K, G$ を求める. 第 2 ステップでは，前ステップで得られた $K, G$ を用い て解き， $A_{2}$ を得る. $A_{i}$ と $A_{i-1}$ の応力を比較し，之の誤 差があらかじめ定められた収束誤差内に収まるまで，同 一の変形量に対して計算を続行し， $A_{n}$ を得る．収束誤 差の判定にあたっては, 全領域の要素を対象としている. 次に, $A_{n}$ の応力から計算される $K, G$ を用いて，次の
変形を与えたときの解を $B_{1}$ として求める. $B_{1}$ から $B_{m}$ に至る過程は， $A_{1}$ から $A_{n}$ を求める手法と同様である。 上記の手法により， $A_{n}, B_{m}, C_{1}, \cdots$ 亡順次, 非線形解を 求めることができる。一方，式（10)，(11）を用いた線 形異方弾性体の場合も, 同一の解析コード (NEAC) に含まれており，適宜選択して解析できることが特徴と いえる。

\section{6. 実験值と解析結果の比較}

\section{（1）非線形異方弾性体}

実験結果を用いて, 式（8）の妥当性を検討する. Table 1 に示す岩石供試体において, クラックの力学性 に関するパラメーター $\left(K_{0}, C, G_{0}, G_{1}\right)$ が全供試体を通 して一定であるとし，クラックの幾何学性に関するパラ メーター $(\boldsymbol{F}, \boldsymbol{N})$ と基質部のヤング率 $E$ のみが各供試 体で異なる場合の解析結果と，実験值との比較を行う。

Fig.8の (a) から (d) は, Table 1 の Rock 2 から Rock 5 に対応する供試体の一軸圧縮試験結果であり, それぞれ実験值を実線で, 解析値を破線で示している。 グラフの横軸は軸方向ひずみ, 縦軸は軸方向の応力を基 質部のヤング率 $E$ で無次元化した值であり, 実験値の 場合，横軸は平均ひずみである，また，図中には各供試 体の基質部のヤング率 $E$ を示してある. 実験では, 除荷, 再載荷の応力経路に従う例もあるが, $F_{0}=3.99 \sim 16.4$ に至るいずれの場合にも，解析結果は実験値をよく説明 している.なお，解析に用いた基質部のポアンン比は, ロゼットゲージによる計測から求めた平均值として,す ベてのケースで $\nu=0.131$ を採用した。 また，クラック の力学性に関するパラメーターは, Table 1 の ROCK 2 に対して Fig. 5 および Fig. 6 から求めた值を直接用いる ことも可能である ${ }^{26)}$. ただし，Fig. 5 および Fig. 6 の計 測に用いられたクラックは, ROCK 2 に含まれるクラッ クのうち，ほぼ最大のものであり，また，供試体を $1 つ$ の領域と考えたときに, クラックの両端が，その領域を 貫いている。このような領域を等価な弾性体に置き換え

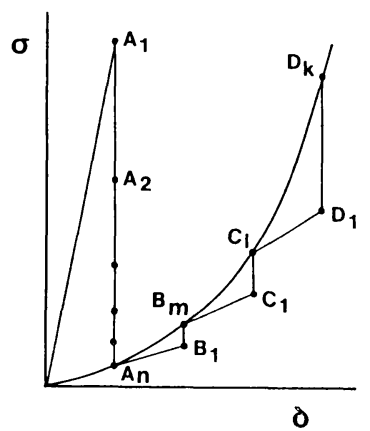

Fig. 7 Iteration method for Non-linear Elastic Analysis by Crack tensor theory (NEAC). 


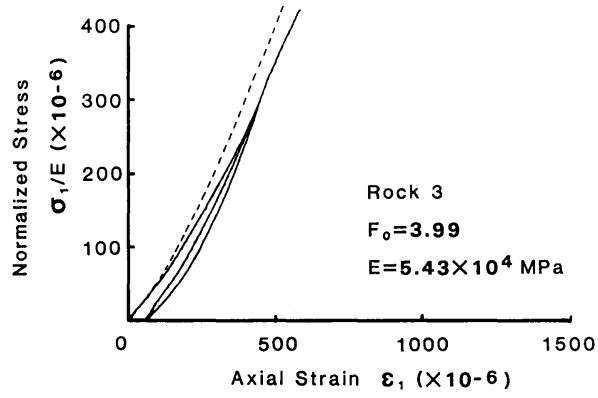

(a) Rock 3

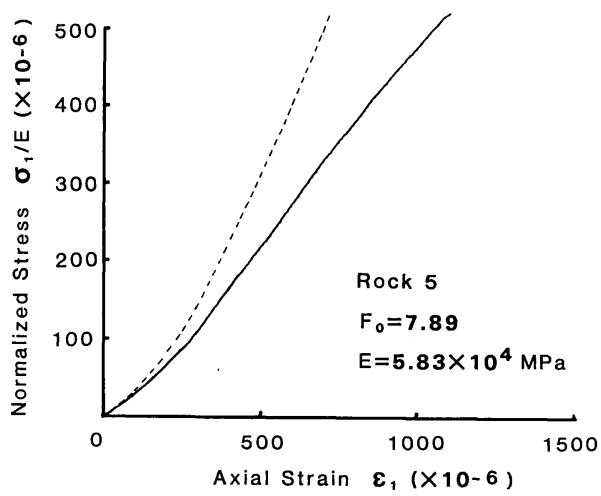

(b) Rock 5

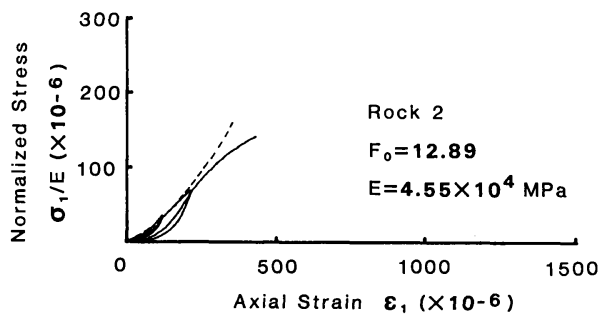

(c) Rock 2

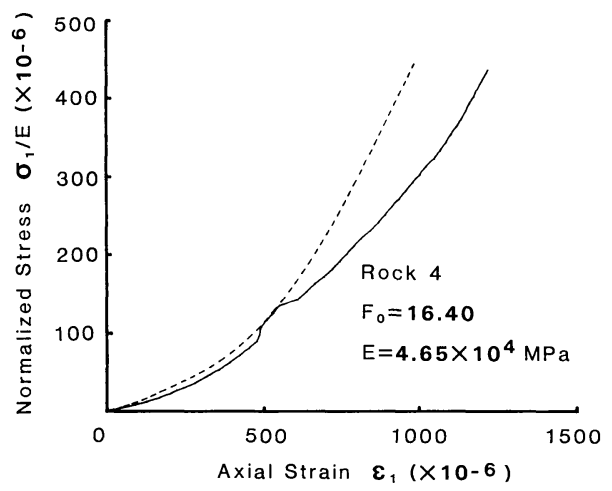

(d) Rock 4

Fig. 8 Comparison between experiment (-) and calculation (‥) for mylonite sample.

て，その力学的性質を決定する際に，上述のような最大 長さのクラックを代表例に採用することの是非について は, 慎重な検討が必要である.したがって, 本解析では,
より一般性の高い方針で，式（3），（4）に含まれる各 パラメーターを決定した。 まず， $K_{0}, G_{0}$ に関しては, ク ラック形状を penny-shape に仮定した弾性解を利用し て $K_{0}=G_{0}=3 \pi E / 8$ とした。 ここで, $E$ は基質部分のヤ ング率である.

次に, $\bar{K}, \bar{G}$ の応力依存性を表現するパラメーター $C, G_{1}$ について考える.すでに考察したように， $K_{0} / C \gamma^{\prime}$ を 1 つの判断基準として $C$ を決定することが可 能であるが，Fig. 4 に示すようなデー夕は諸外国におい ても発表例が限られており，特にわが国においては公表 されたデータが見当たらないことなどを考えると，現時 点では，逆解析的に決定せざるを得ないといえる．G についても，代表として選ぶべきクラック長さを選択す ることが困難である場合には，C と同様，逆解析的に 決定せざるを得ない，ただし，本節の初めでも触れたと おり，本解析においては，クラックの力学性に関するパ ラメーター $\left(K_{0}, C, G_{0}, G_{1}\right)$ が全供試体を通して一定で あるとしたうえで，ROCK 4 のデータを，よく説明す るパラメーター $\left(C, G_{1}\right)$ を選び, 他の供試体の応力-ひ ずみ関係を調べて, Fig. 8 (a) （d) を得た。解析結果 をさらに検討すると， $N_{i j}$ の成分にも依存するが一般に $F_{0}$ が大きいほど, 低応力レベルでの変形量が大きい傾 向や，応力レベルが高くなるにつれ弾性的に挙動する範 囲まで解析が現象を捉えていることがわかる．ただし， 実験において応カレベルがさらに高くなり塑性ひずみが 卓越して応力ーひずみ関係が上に凸となる部分は本解析 手法の適用範囲外であり,この現象を説明するためには, クラックの進展を記述する構成関係と降伏基準 ${ }^{13)}$,221 が必 要であることを付け加えておく.

以上，実測值との比較検討を行い構成式ならびに解析 手法の適用性を確認した．また，上記の収束計算を含む 非線形弾性解析手法によれば初期に有している構造的な 異方性 (inherent anisotropy) のみならず，応力の増加 に伴う場所的な異方性 (induced anisotropy) の効果も 表現できることになる，後者の異方性は，亀裂群の主軸 方向と主応力方向のなす角度にも関係するが, 応力の高 いところほど閉塞する亀裂が卓越し，その傾向が応力の 増加に伴い加速される現象と対応している.さらに応力 レベルが増加すれば，亀裂が閉塞し，その部分は intact な実質部分と同様の変形をすることになる.

\section{（2）線形異方弾性体}

前節で取り上げた応力ーひずみ関係の初期に存在する 非線形性が，対象亡する岩盤あるいはそれに付随する構 造物にとって問題にならない場合，または，非線形解析 をする前の第 1 次近似としての線形異方弾性体の解を求 める場合には, 式 (10)，（11）を適用した線形異方弾性 コンプライアンスによる計算を実施すれば十分であると 
考えられる. 本節では, クラック形状を penny-shape に仮定した線形異方弾性体のコンプライアンスを用いた 有限要素解析結果を示し, 原位置岩盤への適用性につい て検討する.

非線形弾性解析を実施したFig. 8 (a) 〜 (d) の応力ひずみ曲線から，破壊強度の $50 \%$ の応カレベルに対す る割線弾性係数を求めて $E^{\prime}$ とする。この $E^{\prime}$ を基質部 の弾性係数 $E$ で無次元化して縦軸にとり, 横軸を $F_{i j}$ の 11 成分 $F_{11}$ にすれば Fig. 9 となる. 図中の実線は岩 石内部に含まれるクラックを, penny-shape に仮定し式 (10) のコンプライアンスにおいて, 一軸状態 $\left(\sigma_{11} \neq 0, \sigma_{22}\right.$ $\left.=\sigma_{33}=0\right)$ に対応する次式である ${ }^{12}$.

$$
\frac{E^{\prime}}{E}=\frac{1}{(8 / 3 \pi) F_{11}+1} \text {. }
$$

図中の測点に付けた数字は, Table 1 と同一の供武体番 号であり，さらに数本の供試体の結果も加えてある. 本 図により，penny-shape を仮定した線形異方弾性体近似 を用いても広範な $F_{11}$ に対して変形係数の変化を表現で きることがわかる．続いて，Fig. 10 に模式的に示した 異方的なクラック $\left(F_{0}=25.9 ， \xi^{(F)}=0.81\right)$ を含む供試 体に, 上辺から強制変位を与える一軸圧縮試験を解析し た結果を Fig. 11 に示す。同図の横軸は， $F_{i j}$ の最大主 軸方向之鉛直方向のなす角度 $\theta$ であり, 縦軸は, クラッ クを含む供試体のヤング率 $E$ を, クラックを含まない intact な材料のヤング率 $E_{0}$ で無次元化した值である. $E / E_{0}$ は, $\theta=0^{\circ}$ で最小, $\theta=90^{\circ}$ で最大となり, $\lambda^{3}$ が増 大するにつれ，E/ $E_{0}$ は減少することがわかる. Fig. 12 は, 赤井ら ${ }^{23)}$ が緑泥片岩の異方性を実験的に調べた結果 の一部である. 赤井らの論文では角度 $\theta$ の取り方が本 論文と $90^{\circ}$ 異なるため, 論文中のグラフからデー夕を読 み取りプロットし直している. Fig. 11 と Fig. 12 は物性 值，クラックパターンなどの違いにより，直接比較する べきではないが, 両者の定性的な傾向は, よく一致して いる.

次に, Fig. 10 と同一の $F_{i j}$ (クラックパターン) を有 する地盤上で平板載荷試験を行い，その試験結果から $\lambda^{3}$ を決定することを考える.

Fig. 13 中の右上に模式的に示すように，岩盤に強制 変位を与えることを想定した有限要素解析を実施する.

対象とする岩盤の $F_{i j}$ は横坑内の刍裂観察などから, 決 定されていてかつ岩石実質部分の $(E, \nu)$ も既知である とすれば，問題は，実測された地盤反力係数 $H$ を用い て式（11）の $\lambda^{3}$ を求めることと等価である. Fig.13の 縦軸は，クラックを含まない地盤に対して求められる地 盤反力係数 $H_{0}$ で $H$ を無次元化した值であり，横軸は $\lambda^{3}$ を表わす。この $H_{0}$ は，岩石の $(E, \nu)$ が判明してい れば弾性計算で求めることができる. 既知の $F_{i j}$,

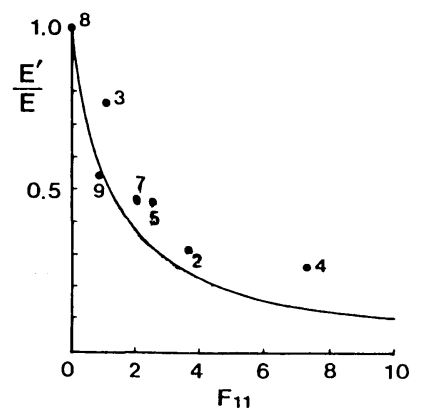

Fig. 9 Normalized deformation modulus vs. $F_{11}$ and theoretical curve.

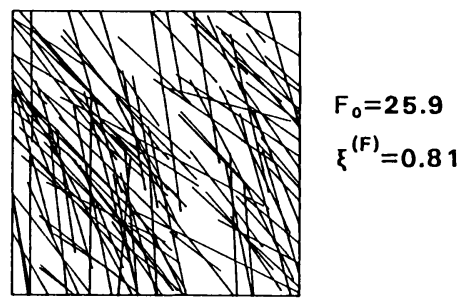

Fig. 10 Two dimensional crack pattern.

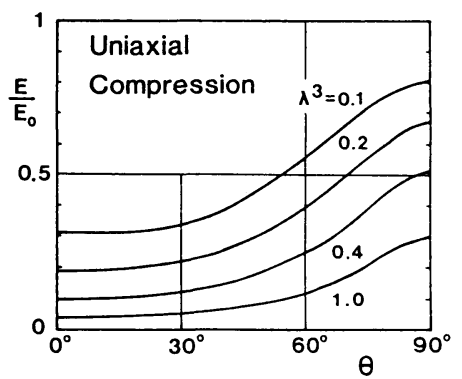

Fig. 11 Change of normalized deformation modulus by anisotropy angle $\theta$ and contact parameter $\lambda^{3}$.

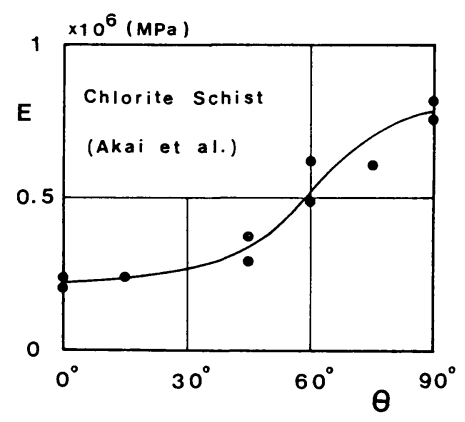

Fig. 12 Change of deformation modulus by angle $\theta$.

$(E, \nu)$ に対して, あらかじめ, $H / H_{0}$ と $\lambda^{3}$ の関係（右 下りの曲線）を計算しておくことも可能であり，グラフ 上で，実測結果との交点 $(\mathrm{A})$ を求め，そのときの $\lambda^{3}$ を決定することができる．しかし， $H / H_{0}$ と $\lambda^{3}$ の関係 をあらかじめ精度よく求めておくためには，多数回の計 


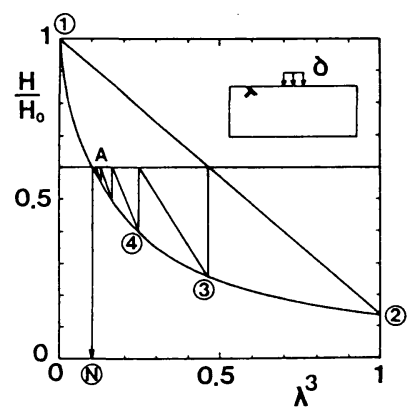

Fig. 13 Determination of contact parameter $\lambda^{3}$ by normalized reaction factor $H / H_{0}$.

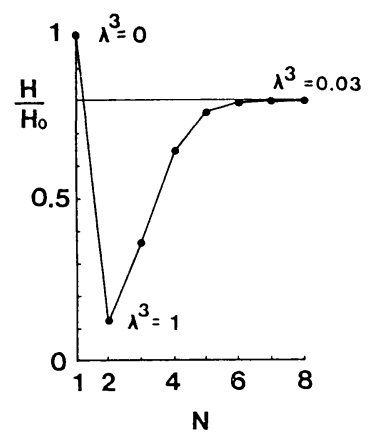

Fig. 14 Convergence of $H / H_{0}$ by iteration number $N$.

算が必要である.そこで, $F_{i j},(E, \nu)$ を既知として $H / H_{0}$ の実测結果（Fig.13では0.6）を用いて， $N$ 回 の計算で $\lambda^{3}$ を求める手順を示す。すなわち，まず等方 線形弾性解 $\left(\lambda^{3}=0\right)$ を求め, 次に, 観察されたクラッ クがすべて penny-shape の場合 $\left(\lambda^{3}=1\right)$ に対応する $H / H_{0}$ を計算する. 次に, 直線(1)(2)と, 与えられた $H / H_{0}$ の交点の $\lambda^{3}$ に対応する $H / H_{0}$ を計算し(3)を得る. 同様の手法により, 順次計算を続行し $N$ 回目に計算し た $H / H_{0}$ と, 与えられた $H / H_{0}$ の誤差が許容值以下に なったときの $\lambda^{3} を$, 求めるべき $\lambda^{3}$ と決定することがで きる. その収束計算過程の一例を Fig. 14 に示す.この 手法により, 原位置平板載荷試験から, クラック内で実 質部分が連結している効果を表わすパラメーター $\lambda^{3} を$ 決定することが可能であり，その $\lambda^{3}$ を用いて，岩盤内 や岩盤上に構造物が建設されたときの線形異方弾性体と しての挙動を, 近似的に推測し得ると考える.

\section{7. あとがき}

クラックテンソルの概念を適用し, 多数の亀裂を含む 岩盤と等価な非線形および線形な異方弾性体の有限要素 解析を行い, 実測值と比較検討した. また, 解析に用い るパラメーターについての考察から, いずれのパラメー ターも原位置で従来実施されている実験から求め得るこ とを示した. しかし, パラメーターの決定方法に関する
妥当性は, 原位置岩盤における調査・試験により一層の 検討を重ねるべきである，さらに，岩盤構造物の安全性 を論じるうえで, 破壊に対する検討が重要であることは いうまでもないが, そのためには本研究の手法に加えて, 亀裂を含む材料の降伏条件や, 亀裂の進展を考慮し得る 一般的な形式をもつ構成関係が必要であることを付記し ておく.

\section{参 考 文 献}

1) Brown, E. T. and Trollope, D. H. : Strength model of jointed rock, ASCE, Vol. 96, SM 2, pp. 685 704, 1970.

2) Einstein, H.H. and Hirschfeld, R. C. : Model studies on mechanics of jointed rock, ASCE, Vol.99, SM 3, pp. 229 248, 1973.

3) Reik, G. and Zacas, M. : Strength and deformation characteristics of jointed media in true triaxial compression, Int. J. Rock Mech. Min. Sci. \& Geomech. Abstr., Vol. 15, pp. 295 303, 1978.

4) Barton, N.R. : A model study of rock joint deformation, Int. J. Rock Mech. Min. Sci. \& Geomech. Abstr., Vol. 9, pp. 579 602, 1972.

5) Bandis, S. et al. : Experimental studies of scale effect on shear behaviour of rock joints, Int. J. Rock Mech. Min. Sci. \& Geomech. Abstr., 18, pp. 1 21, 1981.

6) Goodman, R. E. : Analysis in jointed rocks, in "Finite Elements in Geomechanics" ed. by Gudehus, G., John Wiley \& Sons, pp. 351 375, 1977.

7) Ghabboussi, J. et al. : Finite element for rock joints and interfaces, ASCE, Vol. 99, SM 10, pp. 833 848, 1973.

8) NEA Information Symposium on In-situ Experiments in Granite Associated with the Disposal of Radioactive Waste, 1985.

9) Oda, M. : Fabric tensor for discontinuous geological materials, Soils \& Found., Vol.22, No. 4, pp. 96 108, 1982.

10) Oda, M. : A method for evaluating the effect of crack geometry on the mechanical behaviour of cracked rock masses, Mechanics of Materials, Vol.2, pp. 163 171, 1983.

11) Oda, M. : Similarity rule of crack geometry in statistically homogeneous rock masses, Mechanics of Materials, Vol.3, pp.119 129, 1984.

12) Oda, M., Suzuki, K. and Maeshibu, T. : Elastic compliance for rock-like materials with random cracks, Soils \& Found., Vol.24, No. 4, pp. 27 40, 1984.

13）前渋・小田・数納：クラックテンソルを用いた異方不連 続性材料の破壊規準, 第 17 回岩盤力学に関するシンポジ ウム, pp. 26〜30.

14) Oda, M. : Permeability tensor for jointed rock masses, Geotechnique, Vol. 35, No. 4, pp. 483 495, 1985.

15) Oda, M. : An equivalent continuum model for coupled stress and fluid flow analysis in jointed rock masses, Water Resour. Res., Vol.22, pp. 1845 1856, 1986. 
16）京谷・市川・川本：岩盤の力学特性評価における損傷テ ンソルの適用について, 土木学会論文集 358 , III -3 , pp. $27 \sim 35,1985$.

17）金谷健一：岩盤中のクラック分布の表面観察による測定 法, 第 6 回岩の力学国内シンポジウム, 115 120, 1985.

18) Yoshinaka, R. and Yamabe, T. : Joint stiffness and the deformation behaviour of discontinuous rock, Int. J. Rock Mech. Min. Sci. \& Geomech. Abstr., Vol.23, pp. 19 28, 1986.

19）数納·前渋・小田：亀裂性岩盤の力学的性質, 第 40 回土 木学会年次講演会, III - 341, 681 682, 1985.

20) Bianchi, G. and Snow, D. T. : Pearmeability of crystalline rock interpreted from measured orientation and apertures of fractures, Annals of Arid Zone, Vol. 8, pp. 231 245, 1968.

21) Carlsson, A. and Olsson, T. : Hydraulic properties of Swedish crystalline rocks, Bull. Geol. Inst. Univ.
Uppsala, 71 84, 1977.

22）羽出山・小田：不連続性岩盤の降伏条件, 第 21 回土質工 学研究発表会, pp. 949 950, 1986.

23）赤井・山本・有岡：結晶片岩の構造異方性に関する実験 的研究, 土木学会論文報告集, No. 170, pp. 13 26, 1969.

24）山辺 正：クラックテンソルによる亀裂性岩盤の有限要 素解析, 第 17 回岩盤力学に関するシンポジウム, pp. 16 $\sim 20,1985$

25）山辺・小田・亀村：一般化クラックテンソルによる亀裂 性岩盤の非線形弾性解析, 第 18 回岩盤力学に関するシン ポジウム, pp. 181〜185, 1986.

26）山辺・ 小田・羽出山：節理性岩盤の三次元線形弾性解析, 第 1 回地盤工学における数值解析法シンポジウム, pp. 7 $\sim 14,1986$.

(1986.7.25 - 受付) 